\title{
IDENTIFICATION OF CLOSTRIDIUM CHAUVOEI IN CLINICAL SAMPLES CULTURES FROM BLACKLEG CASES BY MEANS OF PCR
}

\author{
S. Miyashiro¹; A.F.C. Nassar1*; M.C.A.M. Souza ${ }^{1}$; J.B. Carvalho' ${ }^{1}$ J.E.B. Adegas ${ }^{2}$ \\ ${ }^{1}$ Instituto Biológico, São Paulo, SP, Brasil; ${ }^{2}$ Mato Grosso do Sul, Brasil.
}

Submitted: August 11, 2006; Approved: July 05, 2007.

\begin{abstract}
C. chauvoei presence was detected by means of polymerase chain reaction (PCR) from supernatant of culture in cooked meat medium of liver, muscle and metatarsian bone marrow samples of seven calves with blackleg symptoms. The isolation under anaerobic conditions of one muscle sample revealed Clostridium perfringens in pure culture.
\end{abstract}

Key words: Clostridium chauvoei; blackleg; bovine; PCR

Clostridium spp is one of the genera that comprise the group of anaerobic bacteria of considerable medical and economic importance. Clostridiosis is the general name given to a variety of diseases caused by the bacteria of this genus, which can occur in any part of the body that offers condition for their development with consequent toxin production during multiplication (1).

Clostridium chauvoei is the causative agent of blackleg and malignant edema in cattle, sheep and other ruminants (4). Blackleg in cattle is a nontraumatic endogenous infection, and a considerable proportion of bovines may harbor $C$. chauvoei in their liver. Affected animals are anorectic, depressed, febrile, and lame (one side limb), presenting a hot, painful swelling that becomes cold, edematous with crepitation. Death is seen within 12 to 48 hours. This agent seems to have a preference for big muscles (thigh, diaphragm and heart), which at necropsy are dark, red, dry, and spongy (11). Symptoms resembling blackleg can also be caused by Clostridium septicum, $C$. novyi, $C$. perfringens or $C$. sordellii. In a recent study on the phylogenetic position of $C$. chauvoei and $C$. septicum on their 16S rRNA gene ( $r r s$ ) sequences, a similarity of $99,3 \%$ between the $r r s$ genes of $C$. chauvoei and $C$. septicum that is also reflected at the phenotypic level, was determined $(7,8)$.

While presuntive diagnosis of blackleg and malignant edema depends on clinical and pathological findings, the confirmation of disease is typically found by isolating and identifying the organism, such as toxin production and immunological methods
$(9,13)$. However, these diagnostic methods are time consuming and laborious. In addition, immunological methods may yield equivocal results because $C$. chauvoei and $C$. septicum have various antigens in common (4).

Nucleic acid amplification of a specific target region of the bacterial genome by the polymerase chain reaction (PCR) has been widely used for detection and diagnosis purposes (15). The ability of PCR to amplify DNA specifically from low numbers of bacteria, as well as its simplicity, rapidity and reproducibility, offers advantages over conventional methods for identification, and has been actually used to identify many Clostridium species, including $C$. chauvoei in pure cultures and in clinical samples $(5,7,12,14)$. An accurate diagnosis of blackleg is, therefore, often difficult. Standard diagnosis is based on an immunofluorescent assay and on morphological criteria.

In this paper we describe a PCR based method from prior enrichment in cooked meat medium of samples from calves with blackleg to identify $C$. chauvoei. Liver, muscle and metatarsian bone marrow samples from calves that presented blackleg symptoms during brazilian autumn were analyzed. The collected samples were from six calves of a flock from São Paulo State and one calf from Mato Grosso do Sul State (Table 1). All these bovine died suddenly, and presented muscle crepitation in the posterior limb.

Macerated of liver and muscle samples and bone marrow swabs were inoculated into tubes with cooked meat medium

*Corresponding Author. Mailing address: Instituto Biológico - Av. Conselheiro Rodrigues Alves, 1252 - Vila Mariana - São Paulo, SP, Brasil. cep: 04014-002. Tel.: 5511-5087 r.1721. Fax: 5511- 5087 r.1791. E-mail: miyashiro@biologico.sp.gov.br 
(Difco $\left.{ }^{\circledR}\right)$ that right before was subjected to thermal shock $\left(100^{\circ} \mathrm{C}\right.$ for 10 minutes immediately cooled in current water), and then were incubated at $37^{\circ} \mathrm{C}$ for 48 hours. Ten microliters of cooked meat medium were cultured in 5\% sheep blood agar and incubated at $37^{\circ} \mathrm{C}$ for 48 hours under anaerobic conditions. Colonies with characteristic form, aspect, colour and hemolysis were subjected to Gram staining for morphological and cellular wall determination. Suspect isolates were submitted to catalase, lecitinase, gelatinase, glucose, lactose and tumultuous milk coagulation tests for identification of bacterial gender and species.

Guanidine thyocianate based technique (2) was accomplished for DNA extraction from supernatant of tubes with cooked meat medium. One $\mathrm{mL}$ of each tube was centrifuged at $13000 \mathrm{x}$ g for 20 minutes, and the pellet was resuspended in $200 \mu \mathrm{L}$ of Tris-EDTA buffer before the extraction protocol. Multiplex PCR was performed with primers designed for flagelin gene (fliC), described by SASAKI et al. (10), specific for Clostridium chauvoei and Clostridium septicum, that amplify 535 base pairs (bp) and 294 bp, respectively. The forward primer FlaF is common for both species and FlachR and FlaseR are the reverse primers for C.chauvoei and C. septicum, respectively. Amplification of DNA was carried out in a total volume of $50 \mu \mathrm{L}$, with $200 \mu \mathrm{M}$ of each dNTP, $5 \mu \mathrm{L} 10 \mathrm{X}$ reaction buffer, $2,5 \mathrm{mM}$ $\mathrm{MgCl}_{2}, 30$ pmol of each primer (FlaF- 5'AGAATAAACAGAA GCTGGAGATG 3', FlachR- 5'TACTAGCAGCATCAAAT GTACC 3', and Flase R- 5' TTTATTGAATTGTGTTTGTGAAG 3'), 1,25 U Taq polymerase and $10 \mu \mathrm{L}$ of DNA. For amplification, we used thirty cycles divided in three phases as follows: denaturation at $94^{\circ} \mathrm{C}$ for 60 seconds, hybridization at $56^{\circ} \mathrm{C}$ for 60 seconds and extension at $72^{\circ} \mathrm{C}$ for 60 seconds. C. chauvoei $\mathrm{IB}$ 1559 and C. septicum 10518 (Instituto Biológico strains) were used as PCR positive controls, and muscle sample from a normal cow was used as PCR negative control.

PCR was also applied directly from clinical samples (liver, muscle and bone marrow) using the same DNA extraction and amplification protocols cited above. Amplifications were carried out in a Peltier Thermal Cycler-100 (MJ Research) and the analysis of the amplified products was performed by electrophoresis in agarose gel $1.3 \%$ stained with ethidium bromide.

Gram stain of cooked meat medium inoculated with the suspect samples showed small gram-positive rods with subterminal spores in most samples (liver 1, muscles 1,2 and 7 and bone marrows 3,4 and 5), beyond others. However, only in muscle 7 sample was isolated Clostridium perfringens in pure culture, and, no growth was observed in the other samples plates incubated under anaerobic conditions. Multiplex PCR from clinical samples showed no positive result neither for C. chauvoei or C. septicum. However, in the 2006. reaction from supernatant of cooked meat medium inoculated with the same samples, seven of them were positive to $C$. chauvoei and negative to C. septicum (liver 1, muscles 1,2 and 7, bone marrows 3,4 and 5), as seen in Table 1 .

The close phylogenetic relationship between $C$. chauvoei and $C$. septicum is a molecular reflection of the phenotypic similarity of these organisms. C. chauvoei is relatively difficult to distinguish from C. septicum, and, besides, C. septicum can cause symptons very similar to blackleg symptoms $(6,9)$.

GREGORY et al. (3) reported the occurrence and treatment of a bovine with blackleg with high doses of penicilin. Diagnosis was accomplished by isolating $C$. chauvoei from a swab of the myonecrosis area, and guinea pigs inoculation for its identification.

KUHNERT et al. (7) reported a system for distinguishing $C$. chauvoei and C. septicum, however, it requires restriction of enzyme digestion of the PCR products for definitive identification of the organism because of the small difference in the 16S rRNA gene of both bacteria.

Our results show that multiplex PCR reaction based on fliC gene (10) was efficient to identify $C$. chauvoei from naturally infected samples cultured in cooked meat medium accomplishing guanidine thiocyanate for DNA extraction, and differentiate this species from C. septicum. However, PCR results directly from tissue samples were negative, probably due to the low number of clostridial microrganisms, or inefficient DNA extraction protocol.

The isolation of $C$. chauvoei is very difficult, since it requires hard anaerobic conditions, and clinical specimens are often contaminated with other anaerobic bacteria including clostridia in soil, which grow faster than $C$. chauvoei in a culture medium (9). Microbiological culture of muscle 7 revealed Clostridium perfringens isolated in pure culture under anaerobic conditions. This species can also be involved

Table 1. PCR results of analysed samples and their origin. São Paulo,

\begin{tabular}{cccc}
\hline $\begin{array}{c}\text { Animal } \\
\text { identification }\end{array}$ & Origin & $\begin{array}{c}\text { Sample } \\
\text { identification }\end{array}$ & $\begin{array}{c}\text { PCR } \\
\text { C. chauvoei }\end{array}$ \\
\hline $\mathbf{1}$ & SP & Liver 1 & Puscle 1 \\
Liver 2 & Positive \\
$\mathbf{2}$ & SP & Negative \\
& & Buscle 2 & \\
$\mathbf{3}$ & SP & Bone marrow (metatarsus) 3 & Positive \\
$\mathbf{4}$ & SP & Bone marrow (metatarsus) 4 & Positive \\
$\mathbf{5}$ & SP & Bone marrow (metatarsus) 5 & Positive \\
$\mathbf{6}$ & MS & Muscle 7 & Pegative \\
$\mathbf{7}$ & &
\end{tabular}

Legend: SP = São Paulo; MS = MatoGrosso do Sul. 
in blackleg cases, and, in the present study, it could be associated with $C$. chauvoei. Anyway, if only microbiological methods had been applied in this case, blackleg diagnosis would be wrong or incomplete. Clostridial vaccines provide a high degree of immunity against clostridial diseases, and when the diagnosis is correct, the disease can be easily controlled. For this, clinical samples must be properly collected and subjected to laboratory examination. Once all diseases due to clostridia can be prevented by vaccination, if the problem continues despite vaccination, the diagnosis must be wrong. Moreover, a case description is of fundamental importance to conduct laboratorial analysis (1).

Infections due to clostridia microrganisms cause considerable losses in the production, once treatment generally is impracticable. Control and prevention must comprise adequate measures of handling and sistematic vaccination of the flock, since the animals are in permanent contact with the agents and the factors that will be able to unchain the diseases.

Detection of nucleic acid of $C$. chauvoei from prior enrichment of naturally infected samples in cooked meat medium elucidated the diagnosis in these two brazilian outbreaks of blackleg, that usually remains inconclusive because of microbiological culture limitation. Besides, due to high specificity of PCR technique, the employment of guinea pigs for identification of the agent was avoided.

\section{RESUMO}

\section{Identificação de Clostridium chauvoei em cultivos de materiais clínicos de casos de carbúnculo sintomático utilizando-se PCR}

Foi detectada presença de Clostridium chauvoei pela reação de PCR a partir de cultivo em cooked meat medium de amostras de fígado, músculo e medula óssea metatarsiana de sete bezerros acometidos de carbúnculo sintomático. $\mathrm{O}$ isolamento de uma amostra de músculo sob condições anaeróbias revelou Clostridium perfringens em cultura pura.

Palavras-chave: Clostridium chauvoei, carbúnculo sintomático, bovino, PCR

\section{REFERENCES}

1. Baldassi, L. (2005). Clostridial toxins - potent poisons, potent medicines. J. Venom. Anim. Tox. Trop. Dis., 11(4), 391-411.

2. Boom, R.; Sol, C.J.A.; Salimans, M.M.M.; Jansen, C.L.; WertheinVan-Dilen, P.M.E.; Noordaa Van Der J. (1990). Rapid and simple method for purification of nucleic acids. J. Clin. Microb., 28, 495503.

3. Gregory, L.; Della Libera, A.M.M.; Birgel Junior, E.H.; Pogliani, F.C.; Birgel, D.B.; Benesi, F.J.; Miyashiro, S.; Baldassi, L. (2006). Carbúnculo sintomático: ocorrência, evolução clínica e acompanhamento da recuperação de bovino acometido de "manqueira". Arq. Inst. Biol., 73(2), 243-246.

4. Hamaoka, T.; Terakado, N. (1994). Demonstration of common antigens on cell surface of Clostridium chauvoei and Clostridium septicum by indirect immunofluorescence assay. J. Vet. Med. Sci., 56, 371-373.

5. Kojima, A.; Uchida, I.; Sekiaki, T.; Sasaki, Y.; Ogikubo, Y.; Tamura Y. (2001). Rapid detection and identifiation of Clostridium chauvoei by PCR based on flagellin gene sequence. Vet. Microb., 78, 363-371.

6. Kuhnert, P.; Capaul, S.E.; Nicolet, J.; Frey, J. (1996). Phylogenetic positions of Clostridium chauvoei and Clostridium septicum based on 16S rRNA gene sequences. Int. J. Syst. Bact., 46(4), 1174-1176.

7. Kuhnert, P.; Krampe, M.; Capaul, S.E.; Frey, J.; Nicolet, J. (1997) Identification of Clostridium chauvoei in cultures and clinical material from blackleg using PCR. Vet. Microb., 51, 291-298.

8. Moussa, J. (1959). Antigenic formulae for Clostridium septicum and Clostridium chauvoei. J. Path. Bac., 7, 341-350.

9. Sasaki, Y.; Kojima, A.; Aoki, Hiroshi; Ogikubo, Y.; Takikawa, N.; Tamura, Y. (2002). Phylogenetic analysis and PCR detection of Clostridium chauvoei, Clostridium haemolyticum, Clostridium novyi types A and B, and Clostridium septicum based on the flagellin gene. Vet. Microb., 86, 257-267.

10. Sasaki, Y.; Yamamoto, K.; Kojima, A.; Norimatsu, M.; Tamura, Y. (2000). Rapid identification and differentiation of pathogenic clostridia in gas gangrene by polymerase chain reaction based on the 16S-23S rDNA spacer region. Res. Vet. Sci., 69, 289-294.

11. Sippel, W.L. (1982). Diagnosis of Clostridial Diseases. J. Am. Vet. Med. Assoc., 161, 1299-1305.

12. Uzal, F.A.; Plumb, J.J.; Blackall, L.L.; Kelly, W.R. (1997). Detection of Clostridium perfringens producing different toxins in faece of goats by PCR. Lett. App. Microb., 25, 339-344.

13. Vanelli, S.A.; Uzal, F.A. (1996). Clostridium septicum detection by the peroxidase-antiperoxidase (PAP) technique, in formalin-fixed, paraffin embedded tissues of sheep. Arch. Med. Vet., 28, 125-127.

14. Warren, A.L.; Uzal, F.L.; Blackall, L.L.; Kelly, W.R. (1998). PCR detection of Clostridium perfringens type D in formalin-fixed, paraffinembedded tissues of goats and sheep. Lett. App. Microb., 29, 15-19.

15. Whelen, A.C.; Persing, D.H. (1996). The role of nucleic acid amplification and detection in the clinical microbiology laboratory. Ann. Rev. Microb., 50, 349-373. 